\title{
Discussion on the Ideological and Political Construction of the Course "Low Frequency Electronic Circuit" in Non-commissioned Officers College
}

\author{
Li Rong ${ }^{1,{ }^{*}}$, Geng Huafang ${ }^{1, b}$, Hu Changde ${ }^{1}$, Li Ziyang ${ }^{1}$ \\ ${ }^{1}$ Changping College of Non-commissioned Officer, Space Engineering University, No.7, Fuxue Road, Changping \\ District, Beijing, China \\ *abitlirong@163.com \\ b17301062421@163.com
}

\begin{abstract}
The fundamental task of vocational and technical education for non-commissioned officers is to enhancing morality and cultivating cadets for warfare. Curriculum ideology and politics is an important way to realize building morality and cultivating talents. This paper takes the basic course "Low Frequency Electronic Circuits" for noncommissioned officers as an example, discusses the necessity of developing curriculum ideology and politics. It also introduces the methods to implement the curriculum ideology and politics in the professional courses of noncommissioned academies, so as to promote this course to be the same as the ideological and political courses. To move forward, it forms a synergistic effect and give full play to the function of educating people.
\end{abstract}

Keywords-curriculum ideology and politics; low frequency electronic circuit; building morality and cultivating talents

\section{INTRODUCTION}

In 2016, General Secretary Xi Jinping attended the National Conference on Ideological and Political Work in Colleges and Universities, then he delivered an important speech. At the meeting, President Xi emphasized that the ideological and political work of colleges and universities is related to the fundamental issue of what kind of people the colleges and universities cultivate, how to train them, and for whom. It is necessary to persist in taking morality and cultivating talents as the central link and also putting ideological and political work throughout the whole process of education and teaching. Then it will realize the whole process of educating people and all-round education. We should strive to create a new situation in the development of Chinese higher education. Comprehensively promoting the construction of ideological and political courses is a strategic measure to implement the fundamental task of taking morality and cultivating talents. Various courses should go in the same direction with the ideological and political courses to form a synergistic effect [1].

Comrade Mao Zedong once said that the foundation of the army is soldiers. As an important part of the military, non-commissioned officers are in the process of accelerating the development of the cause of socialism with Chinese characteristics and modernization. In order to improve the actual combat capabilities of the troops for winning future information warfare, we must strengthen the construction of the non-commissioned officer team. As a new force of military education, noncommissioned officers' vocational and technical education bears the important task of cultivating highquality skilled non-commissioned officers for our army [2]. This article takes the course "Low Frequency Electronic Circuits", a basic course for noncommissioned officers, as an example, which combines the content of the course to introduce relevant scientific stories. Course ideology and knowledge transfer are integrated. In the teaching process, taking morality and cultivating talents always adheres to the central link. The ideological and political work are through the whole process of education and teaching. It likes that spring weather turns rain, moisturizes things silently. Finally, the ideological and political education is implement. 


\section{BASIC SITUATION OF "LOW FREQUENCY ELECTRONIC CIRCUIT" COURSE}

\subsection{Curriculum Positioning}

The "Low Frequency Electronic Circuit" course is a compulsory basic professional course for noncommissioned vocational technical education students majoring in communications and optoelectronics. It mainly studies various semiconductor devices, electronic circuits and their applications. For non-commissioned officers engaged in communications, measurement and control, surveying and other positions in the army, "Low Frequency Electronic Circuits" will become an indispensable tool in their future professions. This course takes a total of 50 hours, including 30 hours for theory and 20 hours for practice.

This course highlights basic theories, basic concepts, basic laws, basic working principles, basic analysis methods and basic operating skills. And it has the characteristics of application and practice. The course is mainly composed of four parts: basic electronic devices, basic amplifying circuits, basic unit circuits and DC stabilized power supplies. The course focuses on the mastery of basic theories, basic concepts, basic laws, basic analysis methods and basic operational skills, with emphasis on application, practicality and innovation. The teaching goals of this course are divided into knowledge goals, skill goals and quality goals. The knowledge goal is to enable the students to master the knowledge of basic electronic devices, the working principle of the basic single-tube amplifier circuit, the composition of the basic unit circuit and its analysis methods through the study of this course. In terms of skill goal, students should can read the circuit diagram, calculate the performance truth table of the basic amplifying circuit, choose the form and device of the circuit according to actual needs, install and debug the actual circuit. In terms of quality goal, it aims to train students to initially establish system concepts and engineering concepts, technological progress concepts, and innovation concepts. The knowledge points involved in this course lay the foundation for the follow-up study of various professional courses for the professional students, which play an important role in consolidating the basic knowledge of the students and improving the professional quality.

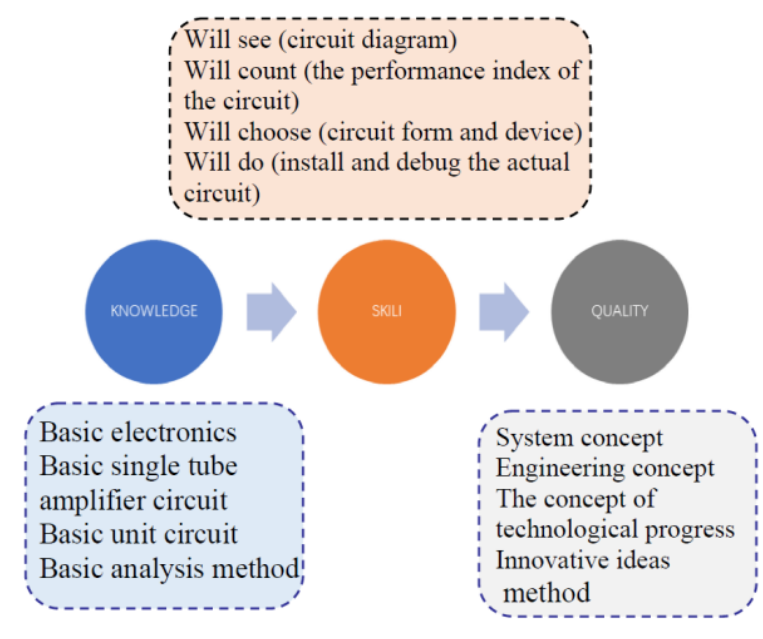

Figure 1. teaching objectives

\subsection{The Necessity of Developing Curriculum Ideology and Politicy}

In this era, various ideological and cultural exchanges are becoming more frequent. Ideological struggles are extremely sharp. And hostile forces at home and abroad are eyeing our army. How to cultivate a strong mainstream ideology, high-quality non-commissioned officers who come upon recruitment, can fight when they come, and must win when they fight, is particularly important. Non-commissioned officers academies are responsible for cultivating high-quality and skilled noncommissioned officers. In the process of education and teaching, non-commissioned instructors should guide non-commissioned officers to establish a correct outlook on the world, life and values. At present, the ideological and political education of non-commissioned officers is mainly based on ideological and political theory courses as the main battlefield and main channel. Other professional basic courses and post courses are mostly based on knowledge transfer. The focus is on cultivating the professional theory or practical skills of the students, and there are few ideological and political content. In fact, professional basic courses like "Low Frequency Electronic Circuits" contain rich philosophical thoughts and humanistic feelings. Hence, it requires teachers to innovate their teaching concepts and teaching methods, improve their teaching models, and design the top-level courses and the classroom teaching process. The teachers should explore deeply the moral education function of the curriculum in the top-level design of the curriculum and the classroom teaching process. And also they should ingeniously integrate knowledge transfer with ideological and political education elements. Finally, the correct ideals, beliefs and value pursuits are silently penetrates into the students. 


\section{WAYS TO CARRY OUT COURSE IDEOLOGY AND POLITICY}

\subsection{Innovative Spirit}

When explaining Zener diodes, firstly students review the four areas of the diode volt-ampere characteristic curve. A question that whether ordinary diodes can work in the reverse breakdown zone and another question that the trend of changes between the voltage and current in the reverse breakdown zone are discussed. Then the working principle of the Zener diode is draw out. When the Zener diode is working normally, the current in the reverse breakdown zone changes in a large range while the voltage remains almost unchanged. This case tells the trainees that Chinese soldiers need the spirit of innovation mostly. Innovation is the core competitiveness of the military. Facing the unpredictable information warfare in the future, if they dare to innovate and recognize the law of war in every training exercise, only then can we drive future wars and achieve the goal of a strong army. There is no end to development and no end to innovation.

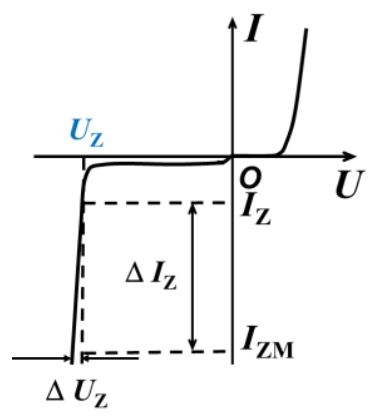

Figure 2. working principle of Zener diode

\subsection{Materialist dialectical thinking}

The transistor is also called the magician with three legs because of its ability to amplify current. For a transistor, in order to have a current amplification function, it must meet certain internal and external conditions. This case helps students understand the principle of internal and external factors in materialist dialectics. The development of things is the result of the joint action of internal and external factors. Internal factors are the basis for the development of things, which

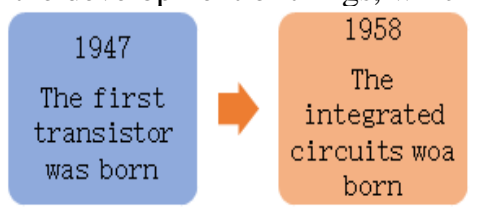

Figure 3. history of electronic technology determine the basic trend of the development of things. External factors are the external conditions for the development of things which plays a role in accelerating or delaying the development of things. The external cause must be passed through the inner and thus act. Internal and external causes are interdependent and interrelated. At the same time, through this case, we can use dialectical materialism to understand Chinese socialist modernization. We must first do a good job in the party's self-building. We should rely on our own lines and policies, and follow the path of socialism with Chinese characteristics. At the same time, in the face of economic globalization, it is necessary to make full use of external conditions to introduce and absorb advanced foreign technology and experience, for promoting the rapid development of Chinese socialist modernization.

\subsection{Craftsman spirit}

The course "Low Frequency Electronic Circuit" belongs to the category of electronic technology. Therefore, in the introduction of this course, we will first introduce the development history of electronic technology to the students. Electronic technology is developed in people's production struggles and scientific experiments. From the original large-scale, high-powerconsuming, complex-manufactured electronic tube to low-power, small-size, stable performance, and low-cost transistors, from discrete components to small-scale integrated circuits, from small-scale integrated circuits to very large-scale integrated circuits, electronic technology has been developing rapidly in just a few decades. Such a rapid development speed depends on the craftsmanship of generations of scientists who are persistent, dedicated, meticulous, and pursuing excellence. This is the starting point for curriculum ideology and politics. The students will be explained the development of Chinese aerospace science and technology, which is also inseparable from the great country craftsman spirit that has been pursuing the institutionalization of professional skills for decades. The craftsman spirit is the precious wealth of Chinese excellent traditional culture. To realize the great rejuvenation of the Chinese nation and speed up the modernization of national defense and the army, we need each of us to actively practice and promote the craftsman spirit, choose one thing, and remain committed to the whole life.

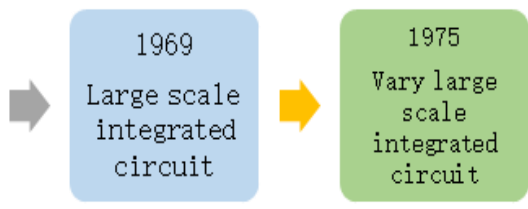




\subsection{Home and country feelings}

When explaining the third module "Overview of Integrated Circuit Development", in addition to introducing the concept of integrated circuits and related performance indicators to the students, it is necessary to expand and explain the current status of Chinese integrated circuit research and development and the gap with the latest technology of advanced countries in the world. Integrated circuit manufacturing technology is the world's highest level of microfabrication technology. It is the strategic commanding height of the global high-tech national power competition. Chinese integrated circuit industry chain is seriously lacking in advanced technology, and heavily dependent on foreign high-end products. Chinese own integrated circuits can only meet about a quarter of domestic demand, and the remaining demand is met by purchasing foreign integrated op amps. Moreover, compared with the latest international technology, Chinese latest integrated circuit technology is one to two generations behind, which has caused China to be "stuck" by the United States in the field of chips. Through this, students will realize that if domestic technology wants to get rid of the dilemma of chip supply and neck choking, we need each of us to have a strong sense of family and country. If we live and die in the country, we should avoid misfortune and fortune. Students are encouraged to integrate their home and country feelings into their unremitting efforts. Their patriotic enthusiasm is stimulated to shoulder the important task of strengthening the army and rejuvenating the army.

\section{Measures for Teaching Reform of "Curriculum Ideology AND Politics"}

Since the introduction of "Curriculum Ideology and Politics ", many military academies and local universities have actively responded to the call and made a lot of attempts in teaching reforms and achieved certain results. However, there are still problems in the implementation of " Curriculum Ideology and Politics". The problems are mainly reflected in the lack of top-level design in the implementation of " Curriculum Ideology and Politics" in some colleges and universities. It is also lacking of clear goal positioning of certain courses. The principles and requirements of ideological and political education are not related to curriculum design, teaching material development, and curriculum implementation. Some teachers lack ideological and political knowledge, and do not have a deep understanding of Chinese excellent traditional culture, party history, and relevant national policies. It is difficult to integrate " Curriculum Ideology and Politics" with professional courses. The ideological and political effects have not formed reasonable and effective evaluation mechanism. In order to effectively promote the "Curriculum Ideology and Politics" teaching and achieve results, it is necessary to conduct in-depth analysis and reflection on the above issues, and explore the reform measures of "Curriculum Ideology and Politics".

\subsection{Pay attention to the improvement of professional course teachers' awareness and ability of "curriculum ideology"}

Teachers are the main body of implementing "curriculum ideology". They are the first person responsible for classroom teaching. Their ideological and political consciousness, ability and quality of teachers determine whether the "Curriculum Ideology and Politics" can be effectively implemented. Professional course teachers are usually proficient in their own research fields and do not have a deep grasp of ideology and politics. Therefore, in the course design and classroom teaching process, we should pay attention to motivating them to implement "Curriculum Ideology and Politics" spontaneously and dig deeper into the ideological and political elements and make effective use of them [3]. At the same time, some professional course teachers worry that the introduction of ideological and political content will compress professional course hours and affect the teaching of professional knowledge points. Such concerns and misunderstandings can be eliminated by organically integrating ideological and political content with professional courses. Professional course teachers need to study Marxism-Leninism, Mao Zedong Thought, Deng Xiaoping Theory, the important thought of "Three Represents", the scientific development view, and Xi Jinping's thought on socialism with Chinese characteristics in the new era, especially for the noncommissioned officers. The school faculty members must earnestly and repeatedly study Xi Jinping's thoughts on strengthening the army and the policy of military education in the new era. Finally, the integration of value shaping, knowledge transfer and ability training is realized. And also the students' correct world outlook, outlook on life and values are cultivated.

\subsection{Improve the evaluation mechanism of "Curriculum Ideology and Politics" performance}

Performance appraisal is the baton for evaluating the implementation effect of "Curriculum Ideology and Politics". A scientific and reasonable "Curriculum Ideology and Politics" performance appraisal and incentive mechanism is the key to promoting professional course teachers to implement the fundamental mission of moral education and reforming the ideological and political teaching [4]. Therefore, the implementation of ideological and political education in the course of professional course practice can be used as 
an important indicator for teacher assessment. Professional course teachers can be guided to increase the importance of ideological and political education, further improve the level of ideological and political education, and deepen their own thinking in teaching practice. A good teaching atmosphere will be created.

\subsection{Pay attention to the organic integration of "curriculum ideology and politics" and "professional curriculum"}

In the process of curriculum ideology and politics implementation, teachers need to skillfully integrate ideological and political elements with different types of professional courses. They need to find out the conjunction point between "ideological and political content" and professional knowledge, and establish a generative internal correspondence through systematic curriculum design and organic integration. When teachers explain professional knowledge, they need to focus on the students' interests to take the current hot spots and practical problems as the starting point. And also they take the classroom as the starting point, and encourage students to think deeply and discuss in groups. Therefore, the positive effect of "Ideological and political education" and specialty is achieved.

\section{CONCLUSION}

The course "Low Frequency Electronic Circuits" is a basic course for non-commissioned officers in communications, photoelectric measurement, and credit insurance. This course highlights the basic theories of electronic technology and the analysis methods of basic circuits. At the same time, the course contains rich ideological and political elements. For the purpose of cultivating people with morality and education, this paper explores the way to carry out curriculum ideology and politics in the course of "Low Frequency Electronic Circuits". Through multi-angle immersive and immersive education, it can realize value guidance while disseminating knowledge, which is very helpful. The worldview, outlook on life and values of the noncommissioned officer have a subtle influence. The effect of "moisturizing things silently" is achieved.

\section{REFERENCES}

[1] Xi Jinping, "Put ideological and political work through the whole process of education and teaching," Xinhua News Agency, http://www.xinhuanet.com//politics/201612/08/c_1120082577.htm

[2] Zhang Min, Xiao Feng, "Thinking of Ideological and Political Education in Applied Mathematics of Vocational and Technical Education for Noncommissioned Officers," Journal Of Liaoning Provincial College Of Communications, vol. 5, pp84-86, Oct. 2020.

[3] Xi Wei, "Reflections on "Curriculum Ideology and Politics" in the Cultivation of Informationalized Non-commissioned Officers of PAP," Education Teaching Forum, vol. 5, pp. 51-52, 2021.

[4] Chen Xinwu, Cang Yuping and Tu Youchao, "Ideological and political education of Analog Electronic Technology," Journal of Higher Education, vol. 18, pp. 171-176, 2020. 